\title{
Effect of Ethanol Extract of Robusta Coffee (Coffea canephora) on the Function of the Liver and Kidney of Wistar Rat
}

\author{
Dewi Ratih Handayani*, Aditya Gilang Nur Pratama, I Wayan Agus Putra \\ Faculty of Medicine \\ Universitas Jenderal Achmad Yani \\ Cimahi, Indonesia \\ *dewi.ratih@lecture.unjani.ac.id
}

\begin{abstract}
Phytochemical tests of coffee show that coffee contains antioxidant compounds, which play a role in the healing process of disease. However, it is necessary to know the safe dosage of coffee extract used in treating diseases including its effect on important organs such as the liver and kidneys. The purpose of this study was to determine the effect of ethanol extract of Robusta coffee beans on the plasma of AST, ALT, urea, and creatinine of Wistar rats. This study used white male Wistar rats which were divided into Group $K$ (control), Group P1 was given ethanol extract of Robusta coffee beans (EECB) with a dose of $625 \mathrm{mg} / \mathrm{Kg} \mathrm{BW}$, Group P2 with a dose of 1250 $\mathrm{mg} / \mathrm{Kg} \mathrm{BW}$. Group P3 dose $2500 \mathrm{mg} / \mathrm{Kg} \mathrm{BW}$, Group P4 dose $5000 \mathrm{mg} / \mathrm{Kg}$ BW. Examination of ALT, AST, urea, and creatinine by spectrophotometry. The results showed an increase in the mean levels of ALT, AST, and urea rat plasma in the P1-P4 group, and there was a significant difference using the ANOVA test with a p-value $<0.05$. Creatinine levels did not show any difference. PostHoc Tukey test, AST levels significantly increased in the P1-P4 group, ALT increased in the P3 and P4 groups, while urea in the $P 4$ group. The ethanol extract of Robusta coffee beans increased AST levels at a dose of $625-5000 \mathrm{mg} / \mathrm{Kg} \mathrm{BW}$, increased plasma ALT levels at a dose of $2500-5000 \mathrm{mg} / \mathrm{Kg} \mathrm{BW}$, and increased urea levels at a dose of $5000 \mathrm{mg} / \mathrm{Kg} \mathrm{BW}$.
\end{abstract}

Keywords-ALT, AST, coffee, creatinine, urea

\section{INTRODUCTION}

Many coffee plants grow in Indonesia so that Indonesia is one of the largest producing Robusta coffee countries in the world. Apart from being consumed, coffee is also used by the community to prevent and treat diseases, such as diabetes mellitus, improve plasma lipid profiles, treat burns, and also for weight loss $[1,2]$. Coffee not only contains caffeine but also several other compounds which are antioxidant compounds. Phytochemical test studies show that coffee contains antioxidant compounds such as chlorogenic acid, alkaloid compounds, flavonoids, saponins, and tannins [3,4]. The role of antioxidants in coffee has an effect on health and prevents disease. Antioxidants play a role in fighting free radicals that cause disease, which is the basis for preventing oxidative stress.

The widespread consumption of coffee in society, especially to prevent or treat disease, causes further research on the toxic effects of coffee on important organs such as the liver and kidneys.

The liver is a central organ in metabolic processes, including in metabolizing various xenobiotic compounds and organs in metabolic xenobiotics. This process is mediated by the presence of the enzyme Cytochrome P450 (Cyt P450). The ability of the liver in metabolic processes is impaired due to exposure to toxic substances or excessive levels of xenobiotic substances in the body which in turn can cause liver failure. This situation is characterized by an increase in the ALT and AST enzymes in the plasma [5]. Apart from the liver, another important organ is the kidney which functions in the process of filtration and excretion of metabolic products. Chemicals can cause cell damage by a variety of mechanisms. Damage to the glomerulus causes many substances that must be excreted such as urea and creatinine cannot be excreted by the kidneys so that their levels increase in the plasma [6]

This study aims to determine the toxic dose of coffee on liver and kidney function in Wistar rats. Toxic doses are given in 4 stages according to the provisions issued by Badan Pengawas Obat dan Makanan (BPOM) Indonesia, namely the dose of $625,1250,2500$, and $5000 \mathrm{mg} / \mathrm{Kg} \mathrm{BW}$. [7] This study is part of an acute toxicity test that has been conducted in which the acute toxicity test assessed rat weight, rat mortality, and relative organ weight. Toxicity testing using experimental animals as a model is useful for seeing the presence of biochemical, physiological, and pathological reactions in humans to test preparation. Toxicity test results cannot be used absolutely to prove the safety of a substance/preparation in humans but can provide indications of relative toxicity and assist in the identification of toxic effects of exposure to humans occurs [7]. 


\section{METHODS}

This research is experimental laboratory research. Subjects were male white rats Wistar strain with inclusion criteria: male gender, weight 150-250 grams, age 8-10 weeks, and healthy. Before the treatment, the rats were adapted for 7 days. In this study, rats will be maintained by following the applicable rules and procedures in the Experimental Animal Laboratory under the coordination of the Study Center of the Faculty of Medicine, Universitas Jenderal Achmad Yani. The Veterinary Laboratory of the Faculty of Medicine, Universitas Jenderal Achmad Yani, consists of 2 animal maintenance rooms and 1 laundry room, ventilation using a fan, room temperature $22^{\circ} \pm$ $3^{\circ} \mathrm{C}$. Illumination during the day comes from sunlight entering through closed glass windows and lighting in the maintenance room. The size of the cage is under the provisions so that the rats are still able to move and carry out their natural behavior. Weighing of body weight was carried out at the beginning and end of the adaptation period so that the bodyweight of the rats could be monitored and ensure that the rats were in a suitable condition for the experiment.

Robusta coffee in the form of coffee beans is obtained from plantations in Lembang, Bandung. Coffee beans are made into ethanol extract at the ITB Bandung Laboratory. The dry Robusta coffee beans will be extracted using ethanol as a solvent. The extract will be divided into 4 dosage groups, namely the dose of $625 \mathrm{mg} / \mathrm{Kg} \mathrm{BW}, 1250 \mathrm{mg} / \mathrm{Kg} \mathrm{BW}, 2500$ $\mathrm{mg} / \mathrm{Kg} \mathrm{BW}$, and $5000 \mathrm{mg} / \mathrm{Kg} \mathrm{BW}$ based on the dose of toxicity test recommended by Badan Pengawas Obat dan Makanan (BPOM) Republik Indonesia. The number of experimental animals from each required herd was calculated using Federer's formula. Based on these calculations, the number of samples used was 5 rats in each treatment group, so the number of mice needed was 25 rats. Furthermore, the rats were divided into 5 groups which were given the following treatment: Group $\mathrm{K}$ as a control group, where the experimental animals were not given any treatment except water and pellets. Group P1 was given ethanol extract of Robusta coffee beans (EECB) at a dose of $625 \mathrm{mg} / \mathrm{Kg} \mathrm{BW}$. Group P2 was given $\mathrm{EECB}$ at a dose of $1250 \mathrm{mg} / \mathrm{Kg} \mathrm{BW}$. The $\mathrm{P} 3$ group was given EECB at a dose of $2500 \mathrm{mg} / \mathrm{Kg} \mathrm{BW}$. Group P4 was given EECB at a dose of $5000 \mathrm{mg} / \mathrm{Kg} \mathrm{BW}$. After the adaptation period, the P1-P4 group was given a single dose of EECB within 24 hours. Observations were made from the first day to the 14th day by observing whether any rats had died. On the 15th day, examination of ALT, AST, urea, and creatinine by spectrophotometry.

\section{ANALYSIS}

The results were analyzed using the OneWay ANOVA test with a p-value $<0.05$ and followed by Tukey's PostHoc test.

\section{A. Aspects of Research Ethics}

This research has received approval from the Health Research Ethics Commission of the Faculty of Medicine, Universitas Jenderal Achmad Yani No 023 / UH2.11 / 2020 by applying the principles of 3R (Replacement, Reduction, and
Refinement) and $5 \mathrm{~F}$ (freedom from hunger or thirst, discomfort and pain, injury or diseases, freedom to express normal behavior, fear, and distress) because this study uses test animals as research subjects.

\section{RESULTS}

The results of the study on liver and kidney function determined the effects of the ethanol extract of Robusta coffee beans, namely by assessing the levels of ALT, AST, urea, and creatinine. Based on the results of the study, it is known that the average ALT level in all groups of rats that received the ethanol extract of Robusta coffee beans increased compared to the control group. The highest increase was in the P4 group. This shows that the ethanol extract of the Lampung Robusta coffee beans has an effect on liver function, and the increased dose of the ethanol extract of the Lampung Robusta coffee beans will increase the plasma ALT levels of experimental rats.

The AST measurement results of rat plasma showed that in all groups of mice that received Robusta Lampung coffee bean extract, groups P1-P4 experienced an increase in plasma AST levels compared to the mean plasma AST levels in the Control group. The highest mean plasma AST level was in the P4 group who received the ethanol extract of Robusta coffee beans at a dose of $5000 \mathrm{mg} / \mathrm{Kg} \mathrm{BW}$. Increasing the dose of Robusta coffee bean ethanol extract will increase the AST levels of the mice plasma. The results of ALT and AST examination of the mice plasma shows that the use of coffee has an impact on liver function.

The assessment parameter to determine the effect of The ethanol extract of Robusta coffee beans on kidney function was to measure plasma urea and creatinine levels. The kidneys are an excretory organ that results from the metabolism of various substances in the body. To determine the safety of the ethanol extract of Robusta coffee beans against the kidneys, the ureaplasma levels were measured as shown in Table 1. The highest average ureaplasma in rats was in the P4 group. Meanwhile, the mean value of creatinine between the control group and the treatment group was almost the same.

TABLE I. ALT, AST, Ureum, AND CREatinine Plasma leVels

\begin{tabular}{|l|l|l|l|l|}
\hline \multirow{2}{*}{ Groups } & \multicolumn{4}{|c|}{ Means \pm SD } \\
\cline { 2 - 5 } & \multicolumn{1}{|c|}{$\boldsymbol{L T} \boldsymbol{u} / \boldsymbol{L}$} & \multicolumn{1}{|c|}{$\boldsymbol{A S \boldsymbol { u } / \boldsymbol { L }}$} & \multicolumn{1}{|c|}{ Urea } & Creatinine \\
\hline K & $57.4 \pm 3.1$ & $54.3 \pm 4.3$ & $37.4 \pm 14.2$ & $0.5 \pm 0.1$ \\
\hline P1 & $59.1 \pm 7.1$ & $73.7 \pm 3.6$ & $41.1 \pm 6.7$ & $0.5 \pm 0.1$ \\
\hline P2 & $67.2 \pm 7.4$ & $82.2 \pm 3.5$ & $36.8 \pm 6.0$ & $0.5 \pm 0.4$ \\
\hline P3 & $79.0 \pm 2.0$ & $118.4 \pm 16.9$ & $46.2 \pm 6.2$ & $0.4 \pm 0.1$ \\
\hline P4 & $96.6 \pm 1.5$ & $176.4 \pm 7.1$ & $56.4 \pm 6.8$ & $0.4 \pm 0.0$ \\
P-value & $<0.05$ & $<0.05$ & $<0.05$ & $>0.05$ \\
\hline
\end{tabular}

Note: $\mathrm{K}$ is the control group, Group P1 was given ethanol extract of Robusta coffee bean (EECB) with a dose of $625 \mathrm{mg} / \mathrm{Kg} \mathrm{BW}$, Group P2 with a dose of $1250 \mathrm{mg} / \mathrm{Kg}$ BW. Group P3 dose $2500 \mathrm{mg} / \mathrm{Kg}$ BW, Group P4 dose $5000 \mathrm{mg} / \mathrm{Kg}$ BW. SD: standard deviation. ANOVA tes with $P$ value $<0.05$ 
TABLE II. POSTHoc Tukey TeST OF PLASMa ALT

\begin{tabular}{|l|l|l|}
\hline \multicolumn{1}{|c|}{ Groups } & Groups & p-value \\
\hline $\mathrm{K}$ & $\mathrm{P} 1$ & .988 \\
\hline & $\mathrm{P} 2$ & .127 \\
\hline & $\mathrm{P} 3$ & .001 \\
\hline & $\mathrm{P} 4$ & .000 \\
\hline $\mathrm{P} 1$ & $\mathrm{P} 2$ & .219 \\
\hline & $\mathrm{P} 3$ & .001 \\
\hline $\mathrm{P} 2$ & $\mathrm{P} 4$ & .000 \\
\hline & $\mathrm{P} 3$ & .081 \\
\hline $\mathrm{P} 3$ & $\mathrm{P} 4$ & .000 \\
\hline
\end{tabular}

Note: $\mathrm{K}$ is the control group, Group P1 was given ethanol extract of Robusta coffee bean (EECB) with a dose of $625 \mathrm{mg} / \mathrm{Kg} \mathrm{BW}$, Group P2 with a dose of $1250 \mathrm{mg} / \mathrm{Kg}$ BW. Group P3 dose $2500 \mathrm{mg} / \mathrm{Kg} \mathrm{BW}$, Group P4 dose $5000 \mathrm{mg} / \mathrm{Kg}$ BW. P-value $<0.05$.

The results of the One Way Anova test showed that the levels of AST, ALT, and Urea in all groups showed significant differences. This is different from creatinine levels which show there is no difference in each group. The ethanol extract dosage of Robusta coffee beans ranging from $625 \mathrm{mg} / \mathrm{Kg} \mathrm{BW}$ to 5000 $\mathrm{mg} / \mathrm{Kg} \mathrm{BW}$ did not give a significant difference to the rat plasma creatinine levels.

In Table 2, it can be seen that the results of the PostHoc Tukey test on ALT plasma examination in the P3 and P4 groups given the ethanol extract of Robusta coffee beans showed a significant increase in ALT levels, compared to other groups.

This study shows that the ethanol extract of Robusta coffee beans has an effect on liver function at doses of 2500 and 5000 $\mathrm{mg} / \mathrm{Kg} \mathrm{BW}$, so the use of coffee ethanol extract which is safe for medicinal purposes must use doses below $2500 \mathrm{mg} / \mathrm{Kg} \mathrm{BW}$.

While the results obtained through Tukey's PostHoc test on AST levels showed that The ethanol extract of Robusta coffee beans affected increased plasma AST levels in groups P1, P2, $\mathrm{P} 3$, and $\mathrm{P} 4$ significantly. This means that the ethanol extract of Lampung coffee beans with a dose of $625-5000 \mathrm{mg} / \mathrm{Kg} \mathrm{BW}$ increases levels of plasma AST. Thus, a safe dose for treatment is below $625 \mathrm{mg} / \mathrm{Kg} \mathrm{BW}$. These results are shown in Table 3.

A significant increase in urea levels was seen in the P4 group who received the ethanol extract of Robusta coffee beans with a dose of $5000 \mathrm{mg} / \mathrm{Kg} \mathrm{BW}$ with a p-value $<0.05$. This shows that giving The ethanol extract of Robusta coffee beans at a dose of $5000 \mathrm{mg} / \mathrm{Kg} \mathrm{BW}$ can affect kidney function to excrete urea.

\section{DISCUSSION}

Oxidative stress is a condition where there is an imbalance between antioxidants and oxidants in the body, resulting in disease. This condition can be overcome by providing additional antioxidants in the form of non-enzymatic antioxidants such as flavonoids, ferulic acid, saponins, caffeine, and tannins. These compounds are found in coffee beans. From several studies conducted in vivo and in vitro, it has been proven that the antioxidant compounds in coffee can reduce the effects of free radicals, so they can prevent and treat disease.
However, the dosage used to prove the effect of coffee to prevent and treat disease is different. This causes it to be done a study on the toxic dose of coffee so that it can be known the safe dose of coffee for consumption.

Coffee is a xenobiotic compound. In the body, coffee will be metabolized by the liver and will be excreted by the kidneys as well as other xenobiotic compounds. The content of various compounds in coffee can be thought to be dangerous if consumed excessively. This situation can cause the ability to function organs is exceeded and eventually cause damage.

The liver has a function in the metabolism of various compounds both from outside the body and from within the body. The function of the liver in metabolizing food, drugs, and several other substances classified as xenobiotics is mediated by the enzyme Cyt P450. Some substances that enter the body will undergo biotransformation in the liver. In biotransformation, the process of detoxification of foreign substances (xenobiotic) by Cyt $\mathrm{P} 450$ and enzymes in xenobiotic metabolism occurs.

However, in this biotransformation process, reactive metabolites can be produced as a result of oxidation reactions, so that biochemical changes will occur in the liver after exposure to toxic substances in the form of injury cells. Injured cells can experience repair if the toxicity is reversible, but if the toxicity is irreversible, it can result in cell necrosis until cell death. The mechanisms that occur in injury cells can be enzyme inhibition, reduced number of cofactors, reduced ATP reserves, increased calcium, and so on [8]. In necrotic cells, it can be identified by assessing the increase in the enzyme alanine (ALT) and aspartate (AST) aminotransferase in plasma, and on the histopathological examination will reveal areas of necrosis with cells that have lost nuclei, and inflammatory infiltrates [5]. See table 3 and 4 below.

\section{TABLE III. Posthoc Tukey Test OF Plasma AST}

\begin{tabular}{|l|l|l|}
\hline \multicolumn{1}{|c|}{ Groups } & Groups & p-value \\
\hline $\mathrm{K}$ & $\mathrm{P} 1$ & .015 \\
\hline & $\mathrm{P} 2$ & .001 \\
\hline & $\mathrm{P} 3$ & .000 \\
\hline & $\mathrm{P} 4$ & .000 \\
\hline $\mathrm{P} 1$ & $\mathrm{P} 2$ & .485 \\
\hline & $\mathrm{P} 3$ & .000 \\
\hline & $\mathrm{P} 4$ & .000 \\
\hline P2 & P3 & .000 \\
\hline & $\mathrm{P} 4$ & .000 \\
\hline P3 & P4 & .000 \\
\hline
\end{tabular}

Note: $\mathrm{K}$ is the control group, Group P1 was given ethanol extract of Robusta coffee bean (EECB) with a dose of $625 \mathrm{mg} / \mathrm{Kg} \mathrm{BW}$. Group P2 with a dose of $1250 \mathrm{mg} / \mathrm{Kg} \mathrm{BW}$. Group P dose $2500 \mathrm{mg} / \mathrm{Kg} \mathrm{BW}$, Group P4 dose $5000 \mathrm{mg} / \mathrm{Kg}$ BW. P-value $<0.05$. 
TABLE IV. Posthoc Tukey Test of Plasma UReum

\begin{tabular}{|l|l|l|}
\hline \multicolumn{1}{|c|}{ Groups } & Groups & p-value \\
\hline $\mathrm{K}$ & $\mathrm{P} 1$ & .470 \\
\hline & $\mathrm{P} 2$ & .954 \\
\hline & $\mathrm{P} 3$ & .163 \\
\hline & $\mathrm{P} 4$ & .005 \\
\hline $\mathrm{P} 1$ & $\mathrm{P} 2$ & .895 \\
\hline & $\mathrm{P} 3$ & .869 \\
\hline & $\mathrm{P} 4$ & .074 \\
\hline $\mathrm{P} 2$ & $\mathrm{P} 3$ & .462 \\
\hline & $\mathrm{P} 4$ & .022 \\
\hline $\mathrm{P} 3$ & $\mathrm{P} 4$ & .457 \\
\hline
\end{tabular}

Note: $\mathrm{K}$ is the control group, Group P1 was given ethanol extract of Robusta coffee bean (EECB) with a dose of $625 \mathrm{mg} / \mathrm{Kg} \mathrm{BW}$, Group P2 with a dose of $1250 \mathrm{mg} / \mathrm{Kg} \mathrm{BW}$. Group P dose $2500 \mathrm{mg} / \mathrm{Kg}$ BW, Group P4 dose $5000 \mathrm{mg} / \mathrm{Kg}$ BW. P-value $<0.05$

From a study, it is said that coffee affects reducing the risk of increasing ALT in someone who is at risk of liver injury [9]. Coffee is known to have a protective effect against chronic liver diseases such as chronic hepatitis, fatty liver, and malignancy [10].

The liver has a vital function in glucose homeostasis, xenobiotics metabolism, and detoxifying toxic substances. Exposure to toxic substances that cause liver cell damage [11]. Although there is a content of caffeine and chlorogenic acid which is an antioxidant, it turns out that the liver's ability to metabolize some toxic substances is beyond the ability of the liver so that there is inflammation that results in increased levels of these enzymes in the blood. When exposed to toxic substances, histologically three mechanisms occur, namely acinus dilation, which is the initial stage, then degeneration of fat, and finally, hepatocyte necrosis, which causes the liver to become small when viewed macroscopically [12].

An important function of the kidneys is to remove metabolic waste substances and xenobiotics from the circulatory system. When this process occurs, the kidneys can become susceptible to toxic substances. The pathway for the elimination of xenobiotics compounds involves glomerular filtration and tubular secretion. Most of the xenobiotics are secreted via the proximal tubule. The substances are between 50-65 kDa in size, they can pass through the glomerulus, while the larger form will be excreted from the circulatory system using transporters. Depending on the physicochemical properties, reactivity, and tendency to bind to intracellular components, a chemical can induce retention in the tubular cells. Changes in the rate or rate of absorption versus excretion of the substance can affect its concentration in the body. Disorders of chemical excretion can cause these substances to accumulate in the body and cause side effects.

In the assessment of kidney function, there was a significant increase in urea levels in the group given the ethanol extract of Robusta coffee beans at a dose of 5000 $\mathrm{mg} / \mathrm{Kg} \mathrm{BW}$. The urea level was influenced by the ethanol extract dosage of Robusta coffee beans. While the effect of ethanol extract of Robusta coffee beans on plasma creatinine levels was not a significant difference in all groups, meaning that the ethanol extract of Robusta coffee beans did not affect rat creatinine. From a study, it is known that long-term caffeine affects kidney function and blood pressure [13-15]. As kidney function decreases, its function in removing various substances including drugs and other metabolites will decrease. This could indicate a condition that there is impaired kidney function.

\section{CONCLUSION}

The ethanol extract of Robusta coffee beans increased plasma ALT levels of Wistar rats at a dose of $2500 \mathrm{mg} / \mathrm{Kg} \mathrm{BW}$ and $5000 \mathrm{mg} / \mathrm{Kg} \mathrm{BW}$ and increased AST levels of rat plasma at a dose of $625-5000 \mathrm{mg} / \mathrm{Kg} \mathrm{BW}$. Meanwhile, the ethanol extract of Robusta coffee beans increased plasma urea levels of Wistar rats at a dose of $5000 \mathrm{mg} / \mathrm{Kg} \mathrm{BW}$.

\section{ACKNOWLEDGMENT}

We would like to thank the Bio Farma Laboratory, Bandung, Indonesia for collaborating in the provision of experimental animals. We also thank the Politeknik Kesehatan Bandung, Indonesia for providing facilities for sample examination.

\section{REFERENCES}

[1] M.C. Cornelis, "The impact of caffeine and coffee on human health.' [online]. Retrieved from https://www.mdpi.com/journal/nutrients

[2] D. Martini, C. Del Bo', M. Tassotti, P.P. Riso, D. Del Rio, and F. Brighenti, "Coffee consumption and oxidative stress: A Review of Human Intervention Studies," 2016, [onlne]. Retrieved from www.mdpi.com/journal/molecules.

[3] N. Liang and D.D. Kitts, "Antioxidant property of coffee components: assessment of methods that define mechanisms of action," Molecules, vol. 19, no. 11, pp. 19180-19208, 2014.

[4] V. Chairgulpraset and K. Kongsuwankeeree, "Preliminary phytochemical screening and antioxidant activity of robusta coffee blossom," Thammasat International Journal of Science and Technology, vol. 22, no. 1, 2017

[5] R.M.M. Santos and D.R.A. Lima, "Coffee consumption, obesity, and type 2 diabetes: a mini-review," Eur J Nutr., vol. 55, no. 4, pp. 1345-58, 2016.

[6] R.G. Schnellmann, Toxic responses of the kidney. In: Toxicology the basic science of poisons. McGraw-Hill education. 2013 8thEd. Chapter 14, 2013, pp. 643-44.

[7] Peraturan Kepala Badan Pengawas Obat dan Makanan Republik Indonesia Nomor 7 Tahun 2014. Pedoman Uji Toksisitas Nonklinik secara In Vivo.

[8] A. Baratloo, A. Rouhipour, M.M. Forouzanfar, S. Safari, M. Amiri, and A. Negida, "The role of caffeine in pain management: A brief literature review," Anesthesiol Pain Med., vol. 6, no. 3, 2016.

[9] C.E. Ruhl and J.E. Everhart, "Coffee and caffeine consumption reduce the risk of elevated serum alanine aminotransferase activity in the United States," Gastroenterology, vol. 128, pp. 24-32, 2005.

[10] D.H. Ryan, M. Brahmbhatt, A.C. Tahan, J.A. Ibdah, and V. Tahan, "Coffee: The magical bean for liver diseases," World J Hepatol, vol. 9 no. 15 , pp. 689-696, 2017.

[11] X. Gu and J.E. Manautou, "Molecular mechanisms underlying chemical liver injury,” Expert Rev Mol Med., vol. 14, p. e4, 2017. 
[12] L. Casarett and J. Doull, "Toxicology: The Basic Science of Poisons," Journal of Environmental Pathology, Toxicology and Oncology, vol. 15, pp. 75-78, 2008.

[13] B. George, D. You, M.S. Joy, and L.M. Aleksunes, "Xenobiotic transporters and kidney injury," Adv Drug Deliv Rev., vol. 116, pp.7391, 2017.
[14] S.P. Tofovic and E.K. Jackson, "Effects of Long-Term Caffeine Consumption on Renal Function in Spontaneously Hypertensive Heart Failure Prone Rats," Journal of Cardiovascular Pharmacology, vol. 33, pp. 360-366, 1999.

[15] C. Willson, "The clinical toxicology of caffeine: A review and case study," Toxicol Reports, vol. 5, pp. 1140-52, 2018. 